\title{
INTERNATIONAL CROSS-BORDER SURROGACY: AN ANALYSIS OF THE MALAYSIAN LEGAL POSITION
}

\author{
Majdah Zawawi* \\ Siti Aliza Alias**
}

\begin{abstract}
This article explores the legal implications that arise out of cross border surrogacy arrangements. There is a need to examine the issues that arise out of such surrogacy arrangements because it affects the responsibilities towards the resulting child. The article discusses among others, the problems in determining the legal parents, registration, custody and citizenship of the child. It is submitted that surrogacy arrangements, especially commercial surrogacy undermines the concept of the family and such an arrangement is immoral and opposed to public policy. In discussing these issues, this article first looks at the legality of surrogacy arrangements in Malaysia and around the world. It then analyses the effect of surrogacy arrangements under existing Malaysian laws and examines the possibility of adopting the child in Malaysia. Following that the article then outlines the citizenship issues that arise out of a surrogacy arrangement. A brief discussion on several unsettling issues is then made and the article extrapolates the notion of reproductive responsibility before concluding.
\end{abstract}

Keywords: cross-border reproductive care, international surrogacy, reproductive responsibilities, international adoption

Associate Professor, Islamic Law Department, Ahmad Ibrahim Kulliyyah of Laws, International Islamic University, Malaysia, P.O. Box 10, 52780 Kuala Lumpur. E-mail: z.majdah@iium.edu.my. This paper was presented at the Medico-Legal Conference 2016. Practising Medicine in a Borderless World, 8-9 December 2016, organised by the Medico-Legal Society, Malaysia.

** Lecturer, Legal Practice Department, Ahmad Ibrahim Kulliyyah of Laws, International Islamic University, Malaysia, P.O. Box 10, 52780 Kuala Lumpur. E-mail: alizaalias@iium.edu.my. 


\title{
IBU TUMPANG MERENTASI SEMPADAN ANTARABANGSA: ANALISA KEDUDUKAN UNDANG- UNDANG DI MALAYSIA
}

\begin{abstract}
ABSTRAK
Makalah ini meneroka implikasi perundangan yang timbul daripada urusan ibu tumpang merentasi sempadan. Wujud keperluan untuk memeriksa isu-isu yang timbul daripada urusan ibu tumpang kerana ianya member kesan kepada tanggungjawab terhadap anak yang terhasil. Makalah ini membincangkan, antara lain, masalah-masalah dalam menentukan ibubapa dari segi undang-undang, pendaftaran, hak penjagaan dan kewarganegaraan anak tersebut. Dihujahkan bahawa urusan ibu tumpang, terutamanya ibu tumpang komersil, melemahkan konsep keluarga dan urusan sebegini tidak bermoral dan bertentangan dengan dasar awam. Dalam membincangkan isuisu ini, makalah ini dimulakan dengan melihat kepada kesahan urusan ibu tumpang di Malaysia dan serata dunia. Ianya kemudian menganalisa kesan urusan ibu tumpang di bawah undang-undang Malaysia masakini dan memeriksa kemungkinan anak itu diambil sebagai anak angkat di Malaysia. Ini disusuli dengan menggariskan isu-isu kewarganegaraan yang ditimbulkan oleh urusan ibu tumpang. Selepas itu, perbincangan ringkas mengenai beberapa isu yang belum diselesaikan dikupas. Makalah membuat kesimpulan mengenai tanggapan tanggungjawab reproduktif sebelum menamatkan perbincangan .
\end{abstract}

Kata kunci: penjagaan reproduktif merentasi sempadan, ibu tumpang antarabangsa, tanggungjawab reproduktif, pengambilan anak angkat antarabangsa 


\section{INTRODUCTION}

Infertility has long been perceived as a medical problem that needs to be treated. The quest of assisting infertile couples has now become a booming health industry worldwide. ${ }^{1}$ The era of globalisation has allowed infertile couples to seek for assisted reproductive services not only in their home country but also in any fertility center anywhere in the world. According to Basan, it is estimated that between eleven and fourteen thousand patients in Europe alone engage in cross-border reproductive arrangements annually. ${ }^{2}$ This practice has been referred to as "cross-border reproductive transaction,"3 "cross-border reproductive care," "fertility tourism," and "reproductive tourism". In promoting its health tourism industry, reproductive tourism is also said to have the potential to attract more tourists to Malaysia as their health tourism destination. ${ }^{6}$

1 Ethics Committee of the American Society for Reproductive Medicine, "Crossborder reproductive care: a committee opinion”, Fertil Steril 2013; 100: 645 650, 645. See also Bassan, Sharon.," Shared Responsibility Regulation Model for Cross-Border Reproductive Transactions." 37 Michigan Journal of International Law (2016) Vol. 37 Issue 2, 300-349, 300.

2 This data was obtained from Shenfield, F. et al., "Cross-Border Reproductive Care in Six European Countries”, 25 Hum. Reproduction, (2010), 1361, 1365.

3 Bassan, Sharon. "Shared Responsibility Regulation Model for Cross-Border Reproductive Transactions", 300.

4 Ethics Committee of the American Society for Reproductive Medicine, "CrossBorder Reproductive care: a Committee Opinion”, Fertility and Sterility, Vol. 100, No. 3, September 2013, 645-650.

5 Siti Syahirah Mohd Mutalip, "Promoting Malaysia Through "Fertility Tourism", Journal of Tourism, Hospitality \& Culinary Arts.

6 In 2010, the Malaysian government launched the Economic Transformation Program (ETP) which intended to transform Malaysia into an upper-middle income country with a knowledge based economy. The Government had identified healthcare as one of the twelve National Key Economic Areas (NKEAs). As a result, medical tourism was identified as one of the key contributor to achieving this target. For further reading see Pemandu, "Economic Transformation Programme: A Roadmap for Malaysia. Accessed September 20, 2016, http://pemandu.gov.my. See also Ormond Meghann; et. al. "Medical tourism in Malaysia; how can we better identify and manage its advantages and disadvantages?", Global Health Action (2014) 7 : 25201. 
As for reproductive tourism, literature suggests that Malaysia does have the potential to be the preferred choice for reproductive tourism due to the relatively cheaper costs of treatments offered if compared to neighbouring Singapore.

Most fertility centers around the world offer services such as artificial insemination, in vitro fertilisation, assisted hatching, inter cytoplasmic sperm injection and zygote intra fallopian transfer. However, aside from that, many of these centers also offer donated sperm, ova and embryos as well as surrogacy services. Cross-border surrogacy in particular is being sought after by infertile couples due to strict laws in their home country which prohibit surrogacy, ${ }^{8}$ and cheaper but equally attractive and high standard private healthcare facilities $^{9}$ as well as shorter waiting times in countries that allow commercial surrogacy.

The main issue that this article highlights is whether infertile couples should be allowed to reproduce at whatever costs, especially when it involves the reproductive capacities of third parties and the interests of the resulting child. This article takes the position that too much concentration has been given to the promotion of the reproductive rights of the infertile couples. Instead, equal, if not more, emphasis needs to be given to the responsibilities that come with reproduction. Therefore, it is submitted that whoever reproduces is bound by the responsibilities that come with it. This includes taking responsibility over what happens to the gametes and embryos that are produced, with whom these gametes are shared with and of course, any resulting child that results from this union. This responsibility

7 Siti Syairah Mohd Mutalip, "Promoting Malaysia Through "Fertility Tourism", Journal of Tourism, Hospitality and Culinary Arts, (2012) Vol. 4 Issue 2, 4. An IVF cycle in a private Singapore hospital costs approximately $\mathbf{S} \$ 15,000$, whereas the same treatment cycle would cost around RM12,000 to RM13,000.

8 Ethics Committee of the American Society for Reproductive Medicine, "Crossborder reproductive care: a committee opinion", 646. See also Bassan, Sharon. "Shared Responsibility Regulation Model for Cross-Border Reproductive Transactions", 300.

9 Bassan, Sharon. "Shared Responsibility Regulation Model for Cross-Border Reproductive Transactions", 301. An interesting take on this issue is made by Nadimpally Sarojini, et. al. in their article, "Globalisation of birth markets: a case study of assisted reproductive technologies in India." Globalization and Health (2011), 7:27. In this article the authors identify the movement of reproductive materials is influenced by the economic standing of the couples seeking fertility treatments. They argue that this has raised issues of "structural inequality". 
cannot and should not be borne by others except in cases of death or incapacity.

This article also argues that surrogacy contracts are void under the Malaysian Contracts Act, 1950 because the consideration for such contract is immoral and/or against public policy as mentioned under section 24(e) of the Contracts Act, 1950.

These arguments are arrived at upon an analysis of existing laws that relate to the birth of a child in Malaysia. Due to the absence of a national legislation governing assisted reproductive technologies, therefore, reliance has been made to neighbouring countries that have legislated the practice. Legislations in Singapore, Thailand, India, Australia and the United Kingdom are referred to where relevant.

In discussing these issues, this article firstly looks at the legality of surrogacy arrangements in Malaysia and around the world. It then analyses the effect of surrogacy arrangements under existing Malaysian laws and examines the possibility of adopting the child in Malaysia. The article then outlines the citizenship issues that arise out of a surrogacy arrangement. Following this, a brief discussion on several unsettling issues is made. Finally, it extrapolates the notion of reproductive responsibility before concluding.

\section{LEGALITY OF THE SURROGACY ARRANGEMENTS}

The prevalence of surrogacy in Malaysia, be it among Malaysians or foreigners, has not been documented. This is due to the absence of a national registry on all assisted reproductive technologies ("ART") procedures offered in the country. The government is unable to keep this registry because, until today, Malaysia does not have a legislation that governs ART services offered in the country. There only exists the Code of Practice on Assisted Reproductive Technologies issued by the Malaysian Ministry of Health in 2002 and the Malaysian Medical Council's Guidelines to Assisted Reproduction, which was issued in 2006. Alas, both these guidelines have no legal effect and are at best, ethical guides to be observed by practitioners. 
This is in contrast to the legal developments in neighbouring Thailand and Singapore, which have recently legislated and even banned commercial surrogacy. ${ }^{10}$ Thailand for example, through its Assisted Reproductive Technologies Act, 2015 has banned crossborder surrogacy ${ }^{11}$ due to several controversial surrogacy cases that occurred in recent years. These include the case of Baby Gammy who was born to a Thai surrogate mother pursuant to a surrogacy agreement with an Australian couple. ${ }^{12}$ This is a case of gestational surrogacy gone wrong where the surrogate mother carried the child whose genetic make up was from the commissioning couple. The surrogate gave birth to twins, a girl and a boy. Unfortunately, the boy had Down syndrome and the couples decided to only take the girl and not the boy, who was later cared for by the surrogate mother. Meanwhile, in another separate incident, the Thai police was reported to have raided a condominium of a Japanese man who had recruited the services of surrogate mothers to produce nine children. ${ }^{13}$ The Thai authorities were concerned over the use of surrogates as tools for baby making and baby selling. The Thai government has also criminalised commercial surrogacy imposing a five year imprisonment and/or fine up 100,000 Baht. ${ }^{14}$

Currently, section 21(1) of the Act only allows Thai infertile couples or a Thai national who has married a foreigner for at least three years to be able to resort to surrogacy as an option for their fertility treatment. Sub-section (2) further provides that surrogate mothers must be a blood relative of either of the applicants but may not be their parents or descendant and must have had the experience of being pregnant before. The Act also prohibits the use of the eggs of the surrogate mother to be fertilised by the sperm of the

10 Assisted Reproductive Technologies Act, 2015 which came into force after it was published in the Royal Thai Government Gazette. See also Sayuri Umeda, "Thailand: New Surrogacy Law", Global Legal Monitor. Library of Congress. ( $6^{\text {th }}$ April 2015) accessed on November 21, 2016, http://www.loc.gov/foreignnews/article/thailand-new-surrogacy-law/.

11 See section 23 of the Assisted Reproductive Technologies Act, 2015.

12 David John Farnell and Wenyu Li v. Pattaramon Chanbua and Others [2016] FCWA 17.

13 "Human Trafficking Suspected in Thai Nine-Baby Discovery". The Japan Times. $7^{\text {th }}$ August 2014. Accessed on November 18, 2016, http://www.japantimes.co.jp/news/2014/08/07/national/thai-lawyer-claims-ninebabies-surrogate-kids-japanese-father/\#.

14 See also section 27 and 49 of the Assisted Reproductive Technologies Act, 2015. 
commissioning father. He may only use his wife's ova or donated ova. ${ }^{15}$ In order to protect the child, section 29 also clearly states that the commissioning parents are to be treated as the legal parents of the resulting child and not the surrogate mother.

Meanwhile, Singapore has the Status of Children (Assisted Reproduction Technology) Act 16 of 2013. ${ }^{16}$ Although this Act does not specifically prohibit surrogacy in all its forms, the effect that it leaves on the status of children born as a result of assisted reproduction utilising donated sperm, egg and surrogacy would definitely cause couples wishing to embark on these procedures to think twice. An example can be seen in Section 5 of the Act which provides that the woman and man who provided the egg and sperm that caused a child to be born shall not be treated as the mother and father of the child. Section 6 further acknowledges that the gestational mother in a fertilisation procedure shall be treated as the mother of the child. This would certainly pose difficulties for the commissioning parents in a surrogacy arrangement to claim parentage under the Act. Section 7(2)(a) would further make things complicated for the commissioning father as the section would recognise the husband of the woman of the gestational mother even if the child was not brought about with the sperm of her husband in that marriage, unless it is proven that he did not consent to the procedure. ${ }^{17}$ There is a proviso in section 7(7) which mentions:

If 2 or more men are to be treated as the father of a child by virtue of one or more provisions in this section, only the man who is to be treated as the father of the child earlier in time by virtue of a provision in this section shall be treated as the father of the child. And no other man shall be treated as the father of the child by virtue of any other provision in this section.

\footnotetext{
15 See section 21(3), Assisted Reproductive Technologies Act, 2015.

16 The Law Reform Commission. The Statutes of The Republic of Singapore. Chapter 317A. Revised Edition 2015.

17 Section 9 of the Act acts as a proviso whereby in cases where there was a mistake, negligence, recklessness or fraud that caused the placement of any egg, sperm or embryo used in the fertilisation procedure and this resulted in a child, then an application may be made under section 10 by the person alleging so within two years after the date on which the applicant discovered that the child was born as a result of such fertilisation procedure.
} 
The application of this section however remains to be seen. Many other countries around the world have also banned either commercial surrogacy or any kind of surrogacy all together. ${ }^{18}$ Countries such as Austria, ${ }^{19}$ France, ${ }^{20}$ Germany, ${ }^{21}$ Iceland, ${ }^{22}$ Italy, ${ }^{23}$ Norway, Sweden ${ }^{24}$ and Turkey $^{25}$ are among those strictly prohibiting any form of surrogacy. Other countries such as Australia (Queensland), ${ }^{26}$

18 For further reading on the status of legislations relating to ART around the world, see Majdah Zawawi, "Donated Materials In Assisted Reproductive Technologies: An Ethico-Legal Analysis Of ART Legislations Worldwide", (2010) Journal Of Medical Ethics And History Of Medicine, Vol. 3, No. 2.

19 Act on Procreative Medicine, 1992. See also Bernat, Erwin, "The Austrian Act on Procreative Medicine: Scope, Impacts and Inconsistencies", in Evans, Donald. Et. al. Creating the Child: The Ethics, Law and Practice of Assisted Procreation, Martinus Nijhoff: Netherlands (1996), 325-332.

20 Law 94-654, 1994. For information on the law in France, see Lee and Morgan, 278. For updates see Health Canada, "Assisted Human Reproduction Internationally", Healthy Living, accessed on October 5, 2006, http://www.hcsc.gc.ca/hl-vs/reprod/hc-sc/general/international_e.html . See also Jean Cohen, "Regulation of assisted reproductive technology: the French experience," in Textbook of In Vitro Fertilization, edited by Peter R. Brinsden, (London: Taylor \& Francis, 2005), 655.

21 Embryo Protection Act, 1990 accessed on November 20, 2016, http://www.auswaertiges-amt.de.

22 Ritta Burrell, Assisted Reproduction in the Nordic Countries. A comparative study of policies and regulation. (Nordic Committee on Bioethics, October 2005), 28. accessed on November 20,2016, http://www.ncbio.org.

23 Law 40/2004, see Majdah Zawawi, Ethico-Legal Aspects of Assisted Reproductive Technologies in Malaysia: Balancing Rights and Responsibilities, Unpublished PhD Thesis, International Islamic University, Malaysia, 2007, 181 -184 .

24 Burrell, Assisted Reproduction in the Nordic Countries, 8. See also Lee and Morgan, Human Fertilisation \& Embryology, 277. Cited in Majdah Zawawi "Donated Materials In Assisted Reproductive Technologies: An Ethico-Legal Analysis Of ART Legislations Worldwide", above.

25 In Vitro Fertilisation and Embryo Transfer Centres Law, 1987 which had prohibited surrogacy arrangements within Turkey. However, the Legislation Concerning Assisted Reproduction Treatment Practices and Centre, 2010, goes on to prohibit cross-border surrogacy transactions. Turkey is the first country that has legislated against this. For further reading see ZB, Gurtin, "Banning reproductive travel: Turkey's ART legislation and third-party assisted reproduction", Reproduction Biomed Online, (2011) Nov. 23, (5) -555-64.

Surrogacy Parenthood Act, 1988. 
Hong Kong, ${ }^{27}$ Thailand, ${ }^{28}$ and United Kingdom ${ }^{29}$ prohibit commercial surrogacy whilst allowing altruistic surrogacy. The law in Israel $^{30}$ is unique as it not only allows commercial surrogacy but also encourages it. ${ }^{31}$ In fact it also prohibits surrogacy by family members. Before 2015, India had also encouraged commercial surrogacy in order to promote its health tourism industry. ${ }^{32}$ However, this will change when the draft legislation regulating assisted reproductive technologies is passed by the Indian Parliament. ${ }^{33}$ The Assisted Reproductive Technology (Regulation) Bill (Draft Bill) was published for public and stakeholder comments on $30^{\text {th }}$ September 2015. Due to the legal problems that came with the case of Baby Manji and the Balaz case, the Indian government has decided to put in

27 Human Reproductive Technology Ordinance, 2000 which came into force in 2007. Available at http://www.legislation.gov.hk accessed on 21.11.2016. For an earlier comment on the application of this Act see Majdah Zawawi, EthicoLegal Aspects of Assisted Reproductive Technologies in Malaysia: Balancing Rights and Responsibilities, Unpublished $\mathrm{PhD}$ Thesis, International Islamic University, Malaysia, 2007,181 -184.

28 Assisted Reproductive Technology Protection Act B.E. 2558, 2015. For a detailed reading on the position in Thailand see Wanaporn T. "Reproductive Justice Dilemma Under the New Thai Law: Children Born out of Assisted Reproductive Technology Protection Act B.E. 2558.”, SelectedWorks accessed on November 20,2016, http:://works.bepress.com/wanaporn_techgaisiyavanit/1/. Surrogacy Arrangements Act, 1985 whereby section 2 specifically prohibits commercial surrogacy and Human Fertilisation and Embryology Act, 2008, this Act amended the 1990 Act of the same name.

30 The Surrogate Motherhood Agreements (Approval of Agreements and Status of New Born) Law No. 1577, 1996 as cited in Majdah Zawawi, Ethico-Legal Aspects of Assisted Reproductive Technologies in Malaysia: Balancing Rights and Responsibilities. There has been no new amendments to the Act since it was enacted.

31 D.A. Frenkel, "Legal Regulation of Surrogate Motherhood in Israel" Medical Law, (2001) 20(4): 605-12.

32 See Palattiyil, George, "Globalization and Cross-Border Reproductive Services: Ethical Implications of Surrogacy in India for Social Work" International Social Work (2010) 53(5) 686-700.

33 Tariq Ahmad, "India: Draft Legislation Regulating Assisted Reproductive Technology Published", Global Legal Monitor. Library of Congress. accessed November 19, 2016, http//www.loc.gov/foreign-news/article/india-draftlgislation-regulating assisted reproductive-technology-published/. 
more stringent laws to curb cross-border surrogacy. ${ }^{34}$ Once this Act is passed, foreigners will no longer be allowed to opt for commercial surrogacy unless they are married to an Indian citizen. ${ }^{35}$

Meanwhile, Malaysia remains among the countries that still has not legislated any laws relating to any form of ART, together with Russia and Ukraine. Currently, fertility centres in the country has been relying on the Guideline of the Malaysian Medical Council on Assisted Reproduction issued in $2002^{36}$ and reliance has also been made on the Ministry of Health's Code of Practice for Assisted Reproductive Technologies Centres, 2004. ${ }^{37}$ Although a proposed bill to regulate assisted reproductive technologies had been submitted to the Ministry of Health since $7^{\text {th }}$ January $2003,{ }^{38}$ the bill has yet to be brought before the Malaysian Parliament. In 2012, the Ministry of Health held an online public engagement session to seek comments from the public. ${ }^{39}$ Alas, despite the statement that the Bill had been drafted in 2012 and the promise for a second phase of online engagement, to date that remains a promise. It is this situation that has resulted in couples from countries that have prohibited surrogacy laws to search for opportunities in countries like Malaysia that have not regulated the services.

However, for Muslims in Malaysia, a fatwa or religious edict pronounced by the National Fatwa Committee on $12^{\text {th }}$ June 2008 prohibits surrogacy and any form of third party involvement in the reproductive process when couples resort to ART services. The decisions of the National Fatwa Committee is considered as legally

34 It is interesting to note that based on a research carried out by Yuri Hibino et.al. Japanese couples prefer India as a possible surrogacy destination. For further reading see Yuri Hibino et.al., "Attitudes towards cross-border reproductive care among infertile Japanese patients", Environ health Prev Med (20313) 18:477484, 480. Section 60(11)(a). See also Tariq Ahmad, note 33.

36 MMC Guideline 003/2006 accessed on November 20,2016, http://www.mmc.gov.my/accessed.

37 As cited in Majdah Zawawi, Ethico-Legal Aspects of Assisted Reproductive Technologies in Malaysia: Balancing Rights and Responsibilities, 63.

38 Bahagian Amalan Perubatan, "Proposed Legislation for ART Services in Malaysia and Code of Practice and Guidelines for ART Centres", paper presented to the Standing Committee for ART on 10 March, 2005.

39 "Assisted Reproduction Law Facing Hurdles, says D-G." The Star. Online. $6^{\text {th }}$ October 2012. Accessed on November 20, 2016, http://www.thestar.com.my/news/nation/2012/assisted -reproduction-law-facinghurdles-says-dg/. 
binding on all Muslims by virtue of Section 34(3) of the Administration of Islamic Law (Federal Territories) Act, 1993 and any ruling of the National Fatwa Committee is usually respected and followed in the drafting of many laws in Malaysia. The representation from the Jabatan Agama Islam Malaysia (JAKIM) is compulsory and the laws drafted will respect the decisions and will not go against the fatwa issued. Nevertheless, due to the non-existence of legislation to this effect, any Muslims who choose to ignore this fatwa could very well do so and suffer minor legal consequences.

The legal position of surrogacy is also murky for non-Muslims in Malaysia. Should non-Muslim couples choose to partake in a surrogacy arrangement outside of Malaysia, multiple legal issues could arise. Similarly, foreign couples who come to the country will also have to grapple with the legal dilemmas that arise if they choose a Malaysian or non-Malaysian surrogate in Malaysia. Hence, this article concentrates on commercial surrogacy arrangements undertaken by non-Muslims in Malaysia as well as its effects on foreign commissioning couples. The effects on Muslim surrogate mothers as well as couples will be a subject that needs to be considered as a topic ripe for further research. Similarly, the article does not propose to deal with issues arising from altruistic surrogacy.

\section{EFFECT OF SURROGACY ARRANGEMENTS UNDER EXISTING MALAYSIAN LAWS}

The resulting legal complication needs to be viewed based on the following possibilities:

a. A Malaysian married couple contracts with a Malaysian surrogate mother, in Malaysia;

b. A Malaysian married couple contracts with a non-Malaysian surrogate mother, in Malaysia;

c. A Malaysian married couple contracts with a non-Malaysian surrogate mother, outside of Malaysia;

d. A non-Malaysian couple contracting with a Malaysian surrogate mother, in Malaysia;

e. A non-Malaysian couple contracting with a non-Malaysian surrogate mother, in Malaysia; 
These possibilities may have overlapping effects, however, when the issue of foreign couples or foreign surrogates is deliberated, there are legal consequences that would not arise in case of Malaysian commissioning couples or surrogates. These differences will be highlighted where relevant.

\section{Determination of parentage and registration}

The determination of who are the legal parents of a child born out of a surrogacy arrangement is very important because once the baby is born, there is a need to register the baby with the National Registration Department of Malaysia within fourteen days. ${ }^{40}$ Normally, a woman who gives birth to the child will be registered as his mother and her husband is his father. In the case of surrogacy, things are not so straight forward. The fact that surrogacy involves a woman agreeing "to become pregnant and bear a child for another person/persons and to surrender it at birth" $" 11$ in itself results in a quandary as to who should be considered the child's parents.

First is the determination of the mother of the child. Traditionally, the mother of the child is the person who gives birth to the child. Even with advances in ART and surrogacy, the laws in many countries still maintain that the birth mother is the mother of the child. An example can be seen in section 33(1) of the Human Fertilisation and Embryology Act, 2008 which provides that:

The woman who is carrying or has carried a child as a result of the placing of an embryo or of sperm and eggs, and no other woman, is to be treated as the mother of the child.

This is also the position in Western Australia, whereby Section 5 of the Artificial Conception Act, 1985 (WA) provides that the woman who donated the egg that created the embryo will not be treated as the mother of the child. Instead, it is the woman who gave birth to the child who will be treated as the mother of the child. As seen above, the position in Singapore is also similar.

In Malaysia, the traditional presumption that the woman who gives birth to the child will automatically be treated as the child's

\footnotetext{
$40 \quad$ See section 8, Births and Deaths Registration Act 1957.

41 The Guidelines on Assisted Reproduction issued by the Malaysian Medical Council, 2006, see para. 12 on Surrogacy.
} 
mother is also maintained. However, it could be argued by the commissioning parents that although the child is born as a result of a surrogacy arrangement, the child may be considered as the "child of the family" as mentioned under section 2 (1) of the Law Reform (Marriage \& Divorce) Act, a child of both spouses or partners. ${ }^{42}$ In the context of a surrogacy arrangement, since the child is born from the gametes of both or at least one of the commissioning parents', therefore, the child may be considered as the "child of the family". Although this definition has yet to be tested in Malaysian courts, it is doubtful that this approach could stand. This is due primarily to the fact that the child was carried and delivered by a woman who is not married to the commissioning father thus making this approach rather dubious.

Hence, it could be deduced that a child born to a surrogate would have the surrogate mother registered as his birth mother.43 It would seem that the status of the commissioning mother is rather unclear, regardless of whether or not her ova was used.

Aside from this, there are other issues relating to the status of the father of the child. Determining the father of the child in cases of surrogacy arrangements in Malaysia would actually depend on the status of the surrogate mother and whether or not she is married. If the surrogate mother is an unmarried woman, then the child would be born as an illegitimate child. The father of an illegitimate child cannot automatically have his name registered in the child's birth certificate. This is due to the existence of section 13 of the Births and Deaths Registration Act, 1957 which mentions:

Notwithstanding anything in the foregoing provisions of this Act, in the case of an illegitimate child, no person shall as father of the child be required to give information concerning the birth of the child, and the Registrar shall not enter in the Register the name of any person as father of the child except at the joint request of the mother and the person acknowledging himself to be the father of the

42 See Kamala M.G. Pillai, Family Law in Malaysia, Petaling Jaya: Lexis Nexis, 2009, 158.

43 See also Majdah Zawawi, "Commercial Use of the Womb: a Comparative Study of the Legal and Ethical Position of Surrogacy Agreements in the UK, US and the Shari'ah", (2002) Proceedings of the International Conference on Law and Commerce, Ahmad Ibrahim Kulliyyah of Laws: Gombak, p. 193-205. accessed on November 20,2016, http://irep.iium.edu.my/id/eprint/17182. 
child, and that person shall in that case sign the register together with the mother.

Section 13A(2) further provides:

The surname, if any, to be entered in respect of an illegitimate child may, where the mother is the informant and volunteers the information, be the surname of the mother; provided that where the person acknowledging himself to be the father of the child in accordance with section 13 requests so, the surname may be the surname of that person.

It is clear from the above provisions that there exists a proviso that would allow the commissioning father in surrogacy cases to have his name registered as the father of the child, upon the consent given by the surrogate mother. A formal joint application must be made by the surrogate and the commissioning father to the Registrar to have his name registered as father of the resulting child. This can only be done after the Registrar has approved the application. ${ }^{44}$

Some fertility clinics might want to try and overcome the requirements stated above by having the surrogate mother deliver at a designated hospital and have the registration of the commissioning parents be done surreptitiously, and dispensing with having to comply with the above requirements. It is submitted that this is in clear contravention of section 36 of the Births and Deaths Registration Act, 1957 which makes it an offence to willfully make or permit to be made for the purposes of registration any false statement, ${ }^{45}$ or willfully or knowingly furnish or permits to be furnished any false information, touching on any of the particulars required by the Act to be made known, 46 or to make or permit to be made any false entry in any register,47 knowing the same to be false; and for such offence the wrongdoer shall be liable to fine of two thousand ringgit or to imprisonment for two months or to both such fine and imprisonment. Further criminal action could also be taken against any such person as it also violates section 466 of the Penal Code that carries a maximum seven years imprisonment or fine that will be determined by the court.

\footnotetext{
44 See section 13, Births and Deaths Registration Act, 1957.

45 Section 36(a) Registration of Births and Deaths Act, 1950.

46 Section 36(b) Registration of Births and Deaths Act, 1950.

47 Section 36(c) Registration of Births and Deaths Act, 1950.
} 
Another more complicated problem would arise if the surrogate mother was a married woman. Based on a reading of section 112 of the Evidence Act, the husband of the surrogate would be considered as the father of the child. Upon birth of the child, the husband could register his name as the father of the child. This could be a possibility especially if the surrogate mother decided that she wanted to keep the child as her own. The child could also be treated as the "child of the marriage" as mentioned under section 2 of the Law Reform (Marriage \& Divorce) Act. This would definitely be a problem for the commissioning couple. Section 112 of the Evidence Act, 1950 would provide a basis for a woman who has agreed to become a surrogate mother to retract from that agreement and keep the child as her own. If she is married, this section could in fact operate to allow the child to be considered as the legitimate child of her husband. ${ }^{48}$ Thus, the man who had commissioned for the woman to be the surrogate for his child will not be able to sought any legal remedy should the surrogate wishes to keep the child. This section would lead to the belief that the only avenue to disavow the legitimacy of the child would be left in the hands of the surrogate's husband. This may be done by proving that at the time the child was conceived, he and his wife "had no access to each other at anytime when he (the child) could have been begotten". The commissioning couple could of course bring the case to court based on the surrogacy agreement signed between the parties. However, it is argued here that the status of the contract (with regards to the validity) in itself is questionable. This will be discussed next.

\section{The Validity of the Surrogacy Agreement}

Every surrogacy arrangement is backed by a surrogacy agreement that provides for the rights and responsibilities of both the surrogate and the commissioning parents. Resorting to the agreement is done with the hope of ensuring the following:

48 Section 112, Evidence Act, 1950, provides, "The fact that any person was born during the continuance of a valid marriage between his mother and any man, or within two hundred and eighty days after its dissolution, the mother remaining unmarried, shall be conclusive proof that he is the legitimate son of that man, unless it can be shown that the parties to the marriage had no access to each other at any time when he could have been begotten." 
1. The surrogate mothers comply to certain terms to ensure the safety of the child that she is carrying;

2. The agreed amount that must be paid by the commissioning parents to the surrogate mother;

3. The agreement of the surrogate mother to relinquish all parental rights over the resulting child once he or she is born.

This is a mechanism that the commissioning parents use to ensure that the surrogate mother does not later refuse to hand over the child to them. Thus far, there have been no surrogacy cases that has reached the Malaysian courts. Hence, this practice continues to be offered by clinics that are offering surrogacy as an option to infertile couples. However, if a court in Malaysia is faced with a civil suit questioning the validity of a contract of surrogacy, this article submits that it should find the contract as an illegal contract and is therefore void. The paper continues to cite the reasons why this should be so.

\section{Surrogacy Contracts and Its Legal Implications in Malaysia}

The aim of a surrogacy contract is to try and protect the commissioning parents by providing the rights of the commissioning parents and the duties of the surrogate mother. Among the conditions of a valid contract would be the existence of an offer, ${ }^{49}$ which usually comes from the commissioning parents, an acceptance ${ }^{50}$ from the surrogate and consideration ${ }^{51}$ that is given between the parties. In case of surrogacy, consideration is the main problem. The issue would go to the legality of the consideration i.e. the payment of money by the commissioning parents and the carrying of the child in her womb by the surrogate mother and the relinquishment of the child and all rights and responsibilities over him.

Section 24(e) of the Contracts Act, 1950 reads:

The consideration or object of an agreement is lawful unless :-

(e) the court regards it as immoral or opposed to public policy. Every agreement of which the object or consideration is unlawful is void.

\footnotetext{
49 Section 2(a), Contracts Act, 1950.

50 Section 2(b), Contracts Act, 1950.

51 Section 2(d), Contracts Act, 1950.
} 
The issue here is whether the consideration of giving payment to the surrogate to have her carry a child for the commissioning parents may be taken as an immoral consideration.

In interpreting what amounts to an immoral consideration, the court could interpret it firstly by relying on the literal rule of interpretation. Under this rule, the court must take the natural and ordinary meaning of the word. Literally, the word "immoral" means, something, which is not considered as good or right. ${ }^{52}$ It can include anything that is offensive to society's ideas of what is good or right. Meanwhile, according to Black's Law Dictionary defines "immoral acts" as acts, which are "contrary to good morals, inconsistent with the rules and principles of morality which regard men as living in a community, and which are necessary for the public welfare, order and decency". ${ }^{53}$ In furtherance of this, "immoral consideration" is defined as "a contract that is in contrary to public morals and is a consideration that the public will hold to be indecent."

If this literal definition is employed, then we must consider the following:

a. the act of carrying the child of a man to whom the surrogate is not married to with the view of obtaining payment, whether it is right or wrong;

b. the act of giving up a child which was carried in her womb to a couple for a determined amount of money, whether it is right or wrong.

In the Malaysian context, in order for a child to be recognised as the child of a marriage that has rights owed to him or her, that child must be a legitimate child of the marriage ${ }^{54}$ Hence, the act of carrying the child of a man who is not married to the woman carrying that child would certainly be considered as a wrongful act and is therefore immoral. As for giving up a child for a certain payment, it could be considered as child selling, which is not only immoral, but also illegal.

\footnotetext{
52 Longman Dictionary of Contemporary English.

53 Black's Law Dictionary, available on line accessed on November 20, 2016, http://www.the lawdictionary.org.

54 Section 3 of the Guardianship of Infants Act, 1960 provides, "The guardian of the person of an infant shall have the custody of the infant, and shall be responsible for his support, health and education."
} 
The above literal definition of an immoral consideration relates closely to what is viewed as immoral from the view of the public. This could also be supported by another method of statutory interpretation that could be relied on by the courts in interpreting the word "immoral" in section 24(e). The maxim, noscitur a soccis is also appropriate whereby the use of this maxim requires the word to be interpreted by looking at the 'friends' that come with it. Under the section, the word 'immoral' is followed by the word 'public policy'. It could be argued therefore, an 'immoral' consideration would also mean any consideration which is opposed to public policy. In order to claim that the consideration is immoral or against public policy, the Court in the case of Koid Hong Kiat v. Rhina Bhar ${ }^{55}$ mentions that it must be shown that the said act "has a tendency to be injurious to public welfare." Hence, reliance on public policy is not new as there are certain jurisdictions which have also relied on protection of public policy as a reason for prohibiting certain private acts, if it can be shown that such an act could be injurious to public welfare.

In the case of surrogacy, the consideration of giving money for a surrogate to carry and deliver a child could be considered as acts against public welfare because such consideration would result in the commodification of the human womb and also babies. Transferring the control of a child for valuable consideration has long been considered an unlawful act as decided in the case of Khoay Chooi v. Regina $^{56}$ under section 26(1) of the Children and Young Persons Ordinance, 1947. Although this Act has been repealed by the Child Protection Act, 1997, and this Act is further repealed by the Child Act, 2001, the sale of children remains a prohibited act under section 48. As for the act of women offering their services as surrogate mothers, this could be equated to selling their bodies for services, which is similar to prostitutes selling their bodies for sex and for a determined amount of payment. As prostitution is considered as illegal $^{57}$ and opposed to public policy, so does acts of surrogacy which allows women to be exploited by men for a certain amount of payment. ${ }^{58}$ This is no longer a mere possibility as what has happened

[1992] 3 CLJ Rep. 476.

(1955) 21 MLJ 209.

57 Section $372 \mathrm{~B}$ of the Penal Code makes it a crime to solicit for purpose of prostitution.

58 Section 372 of the Penal Code for example makes it a crime for someone to exploit any person for purposes of prostitution. 
in Thailand where a Japanese man was caught with 9 babies as a result of surrogacy arrangements. This has raised suspicion of illegal selling of the babies as well as using the surrogates as part of a human trafficking scheme. In Malaysia, section 15 of the Anti-Trafficking in Persons Act, 2007 makes it an offence to profit from the exploitation of a trafficked person. Section 2 of the Act defines "exploitation" as all forms of sexual exploitation, forced labour or services, slavery or practices similar to slavery, servitude, any illegal activity or the removal of human organs.

Based on the above arguments, it is submitted that the consideration in a surrogacy contract is not a legal consideration as it contravenes section 24(e) of the Contracts Acts, 1950. What then is the effect of the contract? The contract would be considered as an illegal contract which is void. This means neither of the parties can rely on the said contract to enforce any of their rights. This is also in line with the maxim, "ex turpi causa non oritur actio" which means, "no cause of action arises out of an immoral or illegal consideration." For example, the commissioning parents cannot go to court to insist on the surrogate to surrender the child to them. And neither can the surrogate come to court to claim for her payment if she has not yet received any payment from the commissioning parents. Both claims will be dismissed by the court. It is trite law that parties must come to court with clean hands. It would also be against the in pari delicto doctrine, whereby a plaintiff who has participated in a wrong doing may not recover damages resulting from the wrong doing. The court will refuse to award any damages under a contract that has unlawful consideration as it would be assisting in something that is illegal. ${ }^{59}$ The loss will therefore fall where it lies and both parties will get nothing.

Another option that could be explored for the commissioning parents could perhaps be found in the form of an adoption of the resulting child. In order to be able to do this, the commissioning parents would have to fulfill all the conditions for a valid adoption as provided in the Adoptions Act, 1950. This Act caters for the adoption

59 See the case of Lee Nyan Ho v Metro Charm Sdn Bhd [2009] 6 CLJ 626,643where it was held "Should the court grant an order to sustain the claims instituted by the plaintiff, it would be tantamount to the court encouraging or even giving countenance ..to erect. Structures illegally in contravention of laws and that is clearly contrary to public policy". 
procedures for non-Muslims in Malaysia. ${ }^{60}$ A continuation of this discussion is done in the proceeding part of this article.

\section{ADOPTING A CHILD IN SURROGACY ARRANGEMENTS}

In case where the surrogate mother consents and in cases where the surrogate has a husband, both need to consent to this being done. ${ }^{61}$ Section 4(3) of the Adoption Act, 1952 provides that the natural parents of the child must sign a consent form that shows that they agree to relinquish claims over the child. However, that is not all. There remains two further conditions that need to be fulfilled which includes the requirement of continuous care and possession ${ }^{62}$ as well as the need to be in ordinary residence in West Malaysia for three consecutive months after obtaining possession of the child. ${ }^{63}$

However, in cases where the commissioning parents are Malaysians who have opted for surrogacy arrangement outside the country, there is a need to fulfil the requirements for a legal adoption in that country. As for non-Malaysians who have chosen Malaysia as their destination for a surrogacy arrangement, fulfilment of these requirements does not guarantee that they may bring home the child. They must also consider the stringent adoption requirements in their home country. The inability to settle any adoption procedure could mean problems in bringing their child back to their home country. This is evident in the problems faced by the father of Baby Manji. ${ }^{64}$ In this case, a Japanese couple had opted for a surrogacy arrangement in India using the gametes from the commissioning father and donated egg from an anonymous donor. Before the child was born, the commissioning mother opted for a divorce and refused to acknowledge that the child was hers. This caused the commissioning father to also rescind the contract. However, when the child was born, the grandmother of the child i.e. the mother of the commissioning father went to India to take the child home to Japan. Alas, the Indian

60 Norliah Ibrahim et. al. Family Law in Malaysia. (Non-Muslims), IIUM Press: Gombak, 2016,367-397.

61 Section 5(1) of the Adoption Act, 1952.

62 Section 4(4)(a) of the Adoption Act, 1952.

63 Section 4(4)(b) of the Adoption Act, 1952.

64 "Surrogate Mother: Court Steps into Legal No-Man's Land", The Malaysian Insider, $25^{\text {th }}$ December 2009. 
Government refused to recognise the surrogate mother as the legal mother of the child and also refused to issue a passport for the child. The commissioning father was also not allowed to adopt the child as Indian law does not allow single men to adopt. Meanwhile, the Japanese Government also refused to allow entrance into Japan. The child remained in a stateless limbo until finally through intergovernmental negotiations the child was given an Indian passport and the Japanese allowed the child into the country through special arrangements.

This case brings the discussion to another important aspect of cross-border surrogacy arrangements, i.e. the issue of the citizenship of the resulting child.

\section{CITIZENSHIP OF CHILDREN BORN FROM INTERNATIONAL CROSS-BORDER SURROGACY}

The birth of a child within Malaysia does not automatically confer him with rights to citizenship. Hence, Malaysian commissioning parents that resort to foreign surrogacy arrangements may find that the resulting child will not have their citizenship. This is primarily because a child born to a non-Malaysian surrogate mother outside of Malaysia will not be recognised as a Malaysian due to the fact that she is not married to the commissioning father. ${ }^{65}$ This will also be the case even if the surrogate is a Malaysian giving birth outside of Malaysia. ${ }^{66}$ Meanwhile, a child born in Malaysia to a Malaysian surrogate will obtain the citizenship of his birth mother as he will be considered as an illegitimate child. ${ }^{67}$ However, if the child is born in Malaysia to a non-Malaysian surrogate mother, he will not be recognised as a Malaysian citizen. It is obvious that the citizenship of the commissioning parents cannot be passed down automatically to

65 Article 14(1)(a) Part II of the Second Schedule of the Malaysian Federal Constitution provides that in para. 1(b) every person born outside the Federation whose father is at the time of the birth a citizen and either was born in the Federation or is at the time of the birth in the service of the Federation or a State, is considered as a citizen of Malaysia.

66 See note 66 , above.

67 Para 1(a) of Part II of the Second Schedule provides that every person born within the Federation of whose parents one at least is at the time of the birth either a citizen or permanently resident in the Federation. 
the resulting child if they are non-Malaysians, even if the child was born in Malaysia.

The determination of citizenship is also important as it involves the issuance of a valid passport to the child. This will be of special import for foreign commissioning parents when they want to take the child back to their home country. The cases of Baby Manji, Baby Gammy and the Balaz case discussed above clearly shows the difficulties involved when commissioning parents wish to bring their baby back to their home country.

Adoption of the child could possibly be the only answer to this issue. Once the commissioning parents have obtained the legal adoption of the child, for Malaysian commissioning parents, they may apply for the child to be granted Malaysian citizenship. Article 15(2) of the Malaysian Constitution provides this possibility, whereby, subject to Article 18, the Federal Government may cause any person under the age of 21 years of whose parents one at least is (or was at death) a citizen, to be registered as a citizen upon application made to the Federal Government by his parent or guardian.

\section{UNSETTLING ISSUES IN SURROGACY ARRANGEMENTS}

There are several unsettling issues in surrogacy arrangements that may arise, which include the following:

a. If the surrogate mother dies at childbirth, will her family be compensated for the loss?

b. If the child dies at birth, will the surrogate mother still get her payment?

c. If the child is born with a genetic disease or physical disabilities, could the commissioning parents be forced to still accept him as their child?

d. If one or both of the commissioning parents die, would the surrogate mother have the responsibility to care for the child, and if so can she claim from the estate of the commissioning parents? 


\section{REPRODUCTIVE RESPONSIBILITIES}

Existing Malaysian laws, be it for Muslims or non-Muslims, has not outlined clearly what constitutes rights and responsibilities of parents. ${ }^{68}$ This may be due to the presumption that these are inherent knowledge that every parent should know through informal learning. In actual fact, there is a need to legislate these notions so as to ensure that parents are clear on what constitutes their rights and responsibilities, especially when there are practices such as surrogacy being practiced in the society.

If reference is made to Article 18 of the Convention of the Rights of the Child, 1989, it provides:

States Parties shall use their best efforts to ensure recognition of the principle that both parents have common responsibilities for the upbringing and development of the child. Parents or as the case may be legal guardians have the primary responsibility for the upbringing and development of the child. The best interest of the child will be their basic concern.

The practice of surrogacy seems to give more emphasis on the parents' right to reproduce rather than the basic concern for the best interest of the child.

Legislation in England and Scotland are made with these recommendations in mind. Section 3(1) of the English Children Act, 1989 for example defines parental responsibilities as:

...all the rights, duties, powers, responsibilities and authority which by law a parent of a child has in relation to the child and his property.

Meanwhile, Section 1(1) of the Children (Scotland) Act, 1995 outlines four main responsibilities of a parent, which includes to safeguard and promote the child's development, provide direction and guidance, maintain contact and act as a child's legal representative. The Scottish Act has considered parental rights as having the child living with him and having control over the child's upbringing. The government therefore has a duty to ensure that these responsibilities are made clear to all parents. By doing so it would "diminish any

68 Norliah et.al., Family Law in Malaysia. (Non-Muslims), 336. 
misunderstanding that a parent has only rights and no responsibilities." 69

Resort to surrogacy arrangements alters the basic premise that a mother is a woman who gives birth to a child. Cross-border surrogacy takes the problem a step further whereby a child may end up having up to three "mothers" in two or more different countries. He may have a genetic mother whom he may never know ${ }^{70}$ and a birth mother who relinquishes all responsibilities over him $^{71}$ to the commissioning mother who has paid for his birth to be made possible through this method. He may also have two fathers, one of whom he will also never know and a father who has shared the expenses with his commissioning mother or even bear all the costs for his creation.

It is submitted that the primacy placed on individual autonomy, especially when exercising reproductive choices is not suitable for adoption in Malaysia. Many ethico-legal issues relating to crossborder surrogacy remain unresolved. The exercise of individual autonomy must also take into consideration the principles of beneficence, non-maleficence and justice. If this approach were to be applied to situations relating to choices to be made with regard to ART, then resort to any form of surrogacy should not be allowed.

This approach would also be in line with the importance placed on the concept of responsibilities that come when an individual decides to procreate. Parental responsibilities cannot be subjected to merely a "cut and paste" rule that allows individuals to reproduce but refuse to accept the responsibilities that come as a result of reproduction. The rules even allow the transfer of all responsibilities to other persons who may not be related to the child at all. In view of the importance placed on the traditional concept of the family in Malaysia, such rules could have difficulty in being accepted in the

69 Scottish Law Commission, Report on Family Law, No.135, HMSO, Edinburgh, 1992, para 2.1.

70 This is what had happened in the case of Baby Manji, where the commissioning Japanese couple used the sperm from the Japanese commissioning father to fertilise the egg of an anonymous donor. Similarly, in the Balaz case, the German commissioning father's sperm was used to fertilise donated eggs and implanted in a surrogate Indian mother in India. For further reading see Smriti Kak Ramachandran, "Legal tangles hurdle to commissioning couples," The Hindu $28^{\text {th }}$ September 2014, accessed accessed on November 20,2016, http://www.thehindu.com/sunday-anchor/sans-parents-sans-nation-sansprotection.

71 This would be the surrogate mother. 
country. Hence, if reliance were to be made on a particular ethical stand on ART it would be to allow individual choices to be made so long as such choices did not result in jeopardising the responsibilities that come with reproduction and the respect for the traditional concept of the family.

\section{CONCLUSION}

Commercial transactions are rarely emotional. Governed primarily by the law of contract, parties are tied down to the terms and conditions laid out therein. Aside from the basic ethical consideration in ensuring that both parties abide by their words, commercial transactions hardly ever involve emotions.

What is usually charged with emotions is the intimate relationship between a man and a woman and even deeper emotions are evoked when such a relationship results in the birth of a child. This is what usually happens in the natural course of things. Alas, this is the $21^{\text {st }}$ century where many things are no longer natural and emotions no longer run that deep. The case of commercial surrogacy in general, and cross-border surrogacy in particular, shows that while assisting infertile couples achieve their dreams of having a child genetically related to them may seem a noble endeavour, due consideration must also be given to the fates of the surrogate mother as well as the resulting child. In the Malaysian context, the law governing assisted reproductive technologies must be expedited before any similar Baby Manji or Gammy case makes it appearance in the Malaysian courts. 